industrial estate is a long way from the hospital. Rehabilitation is not always a continuous process, as it should be, and in graduating from hospital to an I.R.U. the patient passes from the care of one team to another.

This problem was recognized by the Piercy Committee in 1956, for they recommended that two or three experimental comprehensive rehabilitation centres should be set up. Such a comprehensive centre would be associated with, and located as closely as possible to, a general hospital, and would provide within its boundaries a variety of services, including physiotherapy department, gymnasium, occupational therapy department, and industrial workshops provided by the Ministry of Labour. Specialist services would be readily available and staff would be shared with the hospital.

The Ad Hoc Committee on Rehabilitation set up by the Sheffield Regional Hospital Board (1962) was convinced that comprehensive rehabilitation units should be established in all major clinical areas to serve a minimum population of 250,000 and that I.R.U.s should be incorporated in such centres.

Experience of medical rehabilitation at Garston Manor Medical Rehabilitation Centre over the past nine years has convinced me of the need to transfer the patient progressively from a medical programme to a work programme and thus expedite his return to work. This can best be achieved in a comprehensive rehabilitation centre. It is surely time that the experiment took place.

\section{Summary}

The provisions of the 1944 Disabled Persons (Employment) Act are summarized, and an attempt has been made to estimate their influence on the resettlement of disabled people in work during the past 20 years. There has been a steady expansion in the services provided by the Ministry of Labour. However, fuller use could be made of industrial rehabilitation units, and some of their disadvantages might be overcome by developing comprehensive rehabilitation centres.

\section{REFERENCES}

Fletcher, G. C., and Wheble, V. H. (1964). Brit. med. f., 1, 173.

Piercy, Lord (1956). Report of the Committee of Inquiry on the Rehabilitation, Training, and Resettlement of Disabled Persons. Ministry tation, Training, and Resettlement
of Labour. H.M.S.O., Cmd. 9883 .

Sheffield Regional Hospital Board (1962). Final Report of the Ad Hoc Committee on Rehabilitation.

\title{
Advertisement and Classification of Oral Contraceptives*
}

\author{
ARNOLD KLOPPER, $†$ PH.D., M.D., F.R.C.O.G.
}

Brit. med. F., 1965, 2, 932-933

The use of oral contraceptives has increased very much since the first compound was marketed approximately 10 years ago. An inquiry to leading companies in this country and in the United States engaged in the trade produced estimates varying from 5 million to 20 million women all over the world taking these compounds daily. There is reason to believe that the number of users in Britain is not far short of half a million, and in view of the intensive advertising campaign conducted in Australia in recent years it would be surprising if they were far behind Britain in this respect. These observations need to be made for two reasons ; first, to demonstrate how widespread their use is, and, secondly, to substantiate the claim that they represent a very considerable financial investment, and the commercial interests backing these drugs have at their disposal a formidable machine of medical persuasion. Any attempt to suggest a choice between trade preparations on the basis of their structure can have commercial results far larger than the available scientific facts would justify. It is not intended, therefore, that any preferences should be implied in classification, but merely to list and subdivide the compounds in common use in this country and to indicate in which respect their composition may be expected to influence their action.

The first fact which strikes one about the composition of all 11 oral contraceptives on the British market to-day (Table I) is that all are dispensed with an added oestrogen. It is a matter of common agreement that oestrogens will prevent ovulation by suppressing pituitary gonadotrophin secretion, and one of the likeliest theories of how oral contraceptives act is

\footnotetext{
* Address given at the Annual Clinical Meeting of the British Medical Association, Dundee, 1965.

† Scientific Staff, Obstetric Medicine Research Unit (Medical Research Council), University of Aberdeen.
}

that there is a synergism between the oestrogen and the gestagen, the former suppressing follicle-stimulating hormone (F.S.H.) and the latter luteinizing hormone (L.H.) secretion. This fits with the fact that women on oral contraceptives are, endocrinologically speaking, in a state of medical castration. They produce no endogenous ovarian hormones and give no evidence of the growth of Graafian follicles or corpora lutea. To impose a 28-day cycle on such women is evidence of our adherence to social and lunar convention, not a physiological necessity. In cases where ovulation is not suppressed it is likely that a contraceptive action is exerted at another level-for example, by preventing nidation of the fertilized ovum or by alteration of the cervical mucus.

\begin{tabular}{|c|c|c|c|c|}
\hline Preparation & \multicolumn{2}{|c|}{ Oestrogen (mg.) } & \multicolumn{2}{|l|}{ Progestogen (mg.) } \\
\hline $\begin{array}{lll}\text { Gynovlar } & \ldots & \ldots \\
\text { Anovlar } & \ldots & \ldots \\
\text { Norlestrin } & \ldots & \ldots \\
\text { Volidan } & \ldots & \ldots \\
\text { Conovid } & \ldots & \ldots \\
\begin{array}{l}\text { Conovid E } \\
\text { Previson }\end{array} & & \ldots \\
\begin{array}{l}\text { OrthoNovin } \\
\text { Ovulen } \\
\text { Lyndiol }\end{array} & \ldots \\
\text { Feminor sequential }\end{array}$ & $\begin{array}{c}\text { Ethinyloestradiol } \\
\text { ”, } \\
\text { Mestranol } \\
\text { ”, } \\
\text { ”, } \\
\text {," }\end{array}$ & $\begin{array}{l}0 \cdot 05 \\
0 \cdot 05 \\
0 \cdot 05 \\
0 \cdot 05 \\
0 \cdot 075 \\
0 \cdot 1 \\
0 \cdot 1 \\
0 \cdot 1 \\
0 \cdot 1 \\
0 \cdot 15 \\
\theta \cdot 075\end{array}$ & $\begin{array}{l}\text { Norethisterone acetate } \\
\text { ", ", } \\
\text { Megestrol } \\
\text { Norethynodrel } \\
\text { "’ } \\
\text { Norethisterone } \\
\text { Ethynodiol diacetate } \\
\text { Lynoestrenol } \\
\text { Norethynodrel }\end{array}$ & $\begin{array}{l}3 \cdot 0 \\
4 \cdot 0 \\
2 \cdot 5 \\
4 \cdot 0 \\
5 \cdot 0 \\
2 \cdot 5 \\
2 \cdot 5 \\
2 \cdot 0 \\
1 \cdot 0 \\
5 \cdot 0 \\
5 \cdot 0\end{array}$ \\
\hline
\end{tabular}

The advertisement campaigns by which these compounds are made known to the medical public have been designed with great care in order to direct thought along desired lines. For example, words like testosterone have an unfortunate connotation and are carefully avoided, although all but one of the compounds on the British market are 19-nortestosterone derivatives. It is important to the sale of these drugs that the 
impression that they create an unphysiological state should not gain ground, so that a fanciful resemblance to the physiological state of pregnancy is constantly stressed. In this context much play is made with their supposed relationship to progesterone. This is largely nonsense. Progesterone is not, of itself, particularly active in suppressing ovulation, and there is no particular reason to suppose that it is largely responsible for the failure to ovulate during pregnancy.

How far are oral contraceptives related chemically to progesterone? There are four possible parent substances for synthetic gestagens-testosterone, 19-nortestosterone, 17 $\alpha$-hydroxyprogesterone, and progesterone itself. Their structural formulae are shown in Fig. 1.



Progesterone.

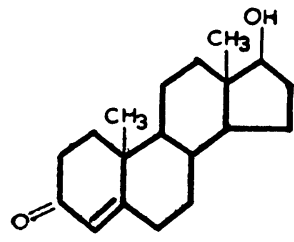

Testosterone.

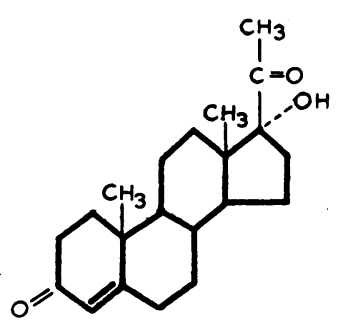

$17 \alpha$-Hydroxyprogesterone.

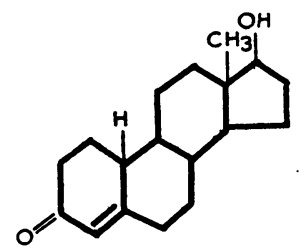

19-Nortestosterone.
FIG. 1.-Parent compounds of synthetic gestagens.

In fact, none of the compounds in use as contraceptives are related to progesterone. Their parent compounds, in the structural sense, are either 19-nortestosterone or, rarely, $17 \alpha^{-}$ hydroxyprogesterone, This is obvious when one looks at the structure of the compound having much the largest share of the British market, norethynodrel. This is shown in Fig. 2.



Norethynodrel.

Trade Name
Conovid
Conovid E
Previson
Feminor
sequential
Enavid
Enavid E

\begin{tabular}{|c|c|c|c|c|}
\hline \multicolumn{2}{|c|}{ Composition } & \multicolumn{3}{|c|}{ Company } \\
\hline \multicolumn{2}{|c|}{ Norethynodrel + mestranol } & $\ldots$ & Searle & \\
\hline " & " & $\cdots$ & Searle & \\
\hline " & $"$ & $\cdots$ & & \\
\hline " & " & $\ldots$ & London & Rubber \\
\hline " & " & $\cdots$ & Searle & \\
\hline
\end{tabular}

Fig. 2.-Nortestosterone derivatives.

The next most common compound, norethisterone, is also a 19-nortestosterone derivative. Its structure is shown in Fig. 3, and it in fact differs from norethynodrel only in the position of one double bond.

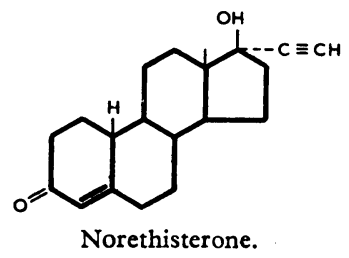

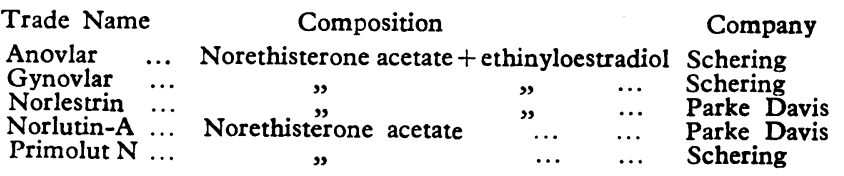

FIG. 3.-Nortestosterone derivatives.

Some of the remaining nortestosterone compounds are noted in Table II.

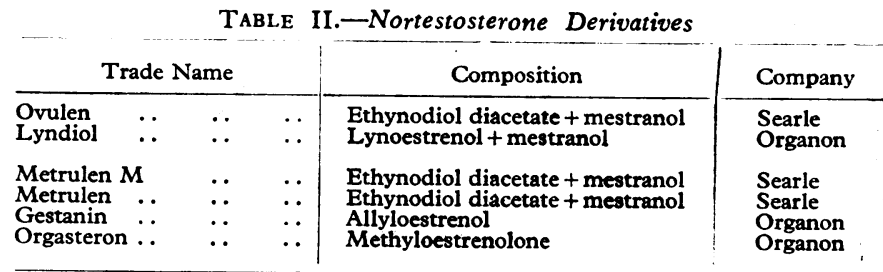

The only oral contraceptives which have even a remote structural connexion with progesterone are $17 \alpha$-hydroxyprogesterone derivatives. They are, however, related to a compound physiologically quite separate from progesterone and itself devoid of any progestational action. Some $17 \alpha$-hydroxyprogesterone derivatives are shown in Table III.

TABLE III.-17 $\alpha$-Hydroxyprogesterone Derivatives

\begin{tabular}{|c|c|c|c|c|}
\hline \multicolumn{3}{|c|}{ Trade Name } & Composition & Company \\
\hline $\begin{array}{l}\text { Volidan } \\
\text { Provera } \\
\text { Farlutal } \\
\text { Lutoral }\end{array}$ & $\begin{array}{l}\cdots \\
\therefore \\
\cdots\end{array}$ & $\begin{array}{l}\cdots \\
\cdots \\
\cdots\end{array}$ & $\begin{array}{l}\text { Megesterol acetate + ethinyloestradiol } \\
\text { Medroxyprogesterone acetate } \\
\text { Medroxyprogesterone acetate } \\
\text { Chlormadinone I }\end{array}$ & $\begin{array}{l}\text { B.D.H. } \\
\text { Upiohn } \\
\text { Farmitalia } \\
\text { Syntex }\end{array}$ \\
\hline
\end{tabular}

Judging by reports in the financial press the steeply rising sales curve of oral contraceptives is now flattening out. This may stimulate the marketing of a new generation of oral contraceptives, the sequential preparations, one of which is already on the British market. There is evidence that they tend to act at a different point from the present compounds. They are, however, the same chemical compounds, merely used in a different dosage scheme, and there is no reason to suppose that they will be essentially different from the present usage.

\section{Summary}

It is argued that in the advertisement of oral contraceptives the manufacturers tend to stress the resemblance of their action to the physiological state of pregnancy, and that they suggest a close relationship between the synthetic gestagens and progesterone.

Evidence is presented that women on oral contraceptives are, endocr nologically speaking, in a state of medical castration rather than pseudo-pregnancy.

It is shown that the chemical ancestry of the synthetic gestagens is unrelated to progesterone. Most are 19-nortestosterone derivatives; a few are derived from $17 \alpha$-hydroxyprogesterone, but this compound is devoid of progestational action. 